\title{
Current state of biology and diagnosis of clonal mast cell diseases in adults
}

\author{
I. ALVAREZ-TWOSE* ${ }^{\dagger}$, J. M. MORGADO* ${ }^{\dagger}$, L. SÁNCHEZ-MUÑOZ ${ }^{*},{ }^{\dagger}$ A. GARCÍA-MONTERO ${ }^{\dagger \ddagger}$,
} M. MOLLEJO ${ }^{\dagger \S}, A$. ORFAO ${ }^{\dagger \ddagger}$, L. ESCRIBANO* ${ }^{\dagger}$

*Instituto de Estudios de Mastocitosis de Castilla La Mancha (CLMast), Hospital Virgen del Valle, Toledo, Spain

${ }^{\dagger}$ Red Española de Mastocitosis (REMA), Toledo, Spain

${ }^{\ddagger}$ Servicio General de Citometría, Centro de Investigación del Cáncer/IBMCC (USAL/CSIC), IBSAL and Departamento de Medicina, Universidad de Salamanca, Salamanca, Spain SServicio de Anatomía Patológica, Hospital Virgen de la Salud,

Toledo, Spain

\section{Correspondence:}

Luis Escribano, Hospital Virgen del Valle, Instituto de Estudios de Mastocitosis de Castilla La Mancha, Carretera de Cobisa s/n, 45071 Toledo, Spain.

Tel.: +34925269335;

Fax: +34925269355;

E-mail: lescribanom@sescam. jccm.es

\section{doi:10.1111/j.1751-553X.2012.01427.x}

Received 31 January 2012; accepted for publication 16 March 2012

Keywords

Mastocytosis, mast cells, biology, diagnosis

\section{SUMMARY}

Mastocytosis comprises a heterogeneous group of disorders characterized by the presence of clonal mast cells (MC) in organs such as skin, bone marrow (BM), and gastrointestinal tract, among other tissues. The clonal nature of the disease can be established in most adult patients by the demonstration of activating KIT mutations in their BM MC. When highly sensitive techniques capable of identifying cells present at very low frequencies in a sample are applied, BM MC from virtually all systemic mastocytosis patients display unique immunophenotypical features, particularly the aberrant expression of CD25. By contrast, large, multifocal BM MC aggregates (the only World Health Organization major criterion for systemic mastocytosis) are absent in a significant proportion of patients fulfilling at least three minor criteria for systemic mastocytosis, particularly in subjects studied at early stages of the disease with very low MC burden. Moreover, recent molecular and immunophenotypical investigations of BM MC from patients with indolent systemic mastocytosis have revealed a close association of some biological features (e.g., multilineage involvement of hematopoiesis by the KIT mutation and an immature mast cell immunophenotype) with an increased risk for disease progression. These observations support the fact that, although the current consensus diagnostic criteria for systemic mastocytosis have been a major advance for the diagnosis and classification of the disease, rationale usage of the most sensitive diagnostic techniques available nowadays is needed to improve the diagnosis, refine the classification, and reach objective prognostic stratification of adult mastocytosis. 


\section{INTRODUCTION}

Despite mast cells (MC) have been long recognized as leading actors in allergic reactions, they have proven to play a role in many other immune and nonimmune responses. After adequate stimuli, MC synthesize and release a wide range of mediators which are involved in the development of clinical symptoms in allergic diseases and also in clonal MC disorders. Because MC are present in virtually all tissues, symptoms and physical signs of the release of MC mediators can involve almost every tissue, particularly the skin, the gastrointestinal tract, and the cardiovascular system.

The term mastocytosis defines a heterogeneous group of rare disorders characterized by the presence of clonal MC in one or multiple organs and tissues. Overall, mastocytosis is considered as a category of myeloproliferative neoplasms as per the 2008 World Health Organization (WHO) [1]; in this classification, diagnosis of systemic mastocytosis (SM) is mainly based on a major histopathological criterion - presence of multifocal dense aggregates of $\geq 15 \mathrm{MC}$ in the bone marrow (BM) and/or other extracutaneous tissues - together with four minor criteria related to BM MC morphology (atypical MC in smears or biopsy sections of BM or other extracutaneous organs), immunophenotypic (CD25+ and/or CD2+ MC) and molecular features (D816V KIT mutation), and biochemical findings (serum tryptase levels persistently $>20 \mu \mathrm{g} / \mathrm{L}$ ) findings. Based on these criteria and the presence $v s$. absence of a group of socalled ' $\mathrm{B}$ ' and ' $\mathrm{C}$ ' findings [1-5], which have been recently reviewed [6] (Table 1), up to seven categories of mastocytosis are defined by the current WHO classification of the disease: cutaneous mastocytosis (CM), extracutaneous mastocytoma, indolent SM (ISM), aggressive SM (ASM), SM associated with other clonal hematological non-MC-lineage disease (SM-AHNMD), MC leukemia (MCL), and MC sarcoma.

In recent years, diagnostic guidelines, algorithms and recommendations to facilitate implementation of the WHO criteria have been proposed and preliminary descriptions of new provisional subvariants have been made [3, 7-13]. These new provisional subtypes of mastocytosis include well-differentiated SM (WDSM) [5, 14-18] and ISM in the absence of skin lesions (ISMs-) [19, 20]. In addition, other clonal MC syndromes not fulfilling criteria for SM have been reported which are generally termed as monoclonal
Table 1. ' $\mathrm{B}$ ' and ' $\mathrm{C}$ ' findings for the diagnosis of aggressive systemic mastocytosis

' $B$ ' findings

Findings associated with disease progression and a variable increase in MC burden which may be also commonly observed also in ISM with multilineal KIT mutation, several years (usually $>5$ years) after disease onset

1. $-\mathrm{BM}$ biopsy with $>30 \%$ infiltration by MC (focal, dense aggregates) by histology (and/or $>1 \%$ by flow cytometry).

-Serum total tryptase levels $>200 \mu \mathrm{g} / \mathrm{L}$ in the absence of diffuse bone sclerosis.

-Development of diffuse bone sclerosis.

-Increased serum $\beta 2$-microglobulin.

-Hypercellular BM with loss of fat cells.

2. -Discrete signs of dysmyelopoiesis in non-MC lineage cells without substantial cytopenias, and WHO criteria for MDS or MPN

3. -Organomegaly (palpable hepatomegaly, splenomegaly and/or lymphadenopathy $>2 \mathrm{~cm}$ on CT or US) without impaired organ function

' $C$ ' findings

Findings associated with impaired organ function because of MC infiltration (e.g. confirmed by biopsy)

1. -Cytopenia $\left(\mathrm{ANC}<1.0 \times 10^{9} / \mathrm{L}\right.$, hemoglobin $<100 \mathrm{~g} / \mathrm{L}$ and/or platelets $<100 \times 10^{9} / \mathrm{L}$ ), because of BM dysfunction with no obvious other non-MC haematopoietic malignancy

2. -Hepatomegaly with impaired liver function and/or ascites

3. -Palpable splenomegaly with hypersplenism

4. -Malabsorption with hypoalbuminemia and weight loss

5. -Skeletal lesions: large-sized osteolytic lesions and/or pathological fractures associated with local MC infiltration (pathological fractures or osteolytic lesions associated with osteoporosis should not be considered a C-finding)

6. -Life-threatening organopathy in other organ systems caused by infiltration of the tissue by neoplastic MC

Source: Modified from reference Escribano et al. [6].

MC, mast cell; ISM, indolent systemic mastocytosis; BM, bone marrow; WHO, World Health Organization; MDS, myelodysplastic syndrome; MPN, myeloproliferative neoplasm; CT, computerized tomography; US, ultrasound; ANC, absolute neutrophil count.

MC activation syndromes [3, 21] or clonal MC activation disorders $[19,22]$.

In practice, the great majority of ISM cases correspond to ISM patients who are typically characterized by low MC burden (particularly at early stages of the disease) and ascribed to the good-prognosis category of 
the disease. In adults, diagnosis of ISM is suspected on the basis of the presence of either mastocytosis in the skin (MIS) and in patients without MIS, anaphylaxis, and other severe symptoms (e.g., cardiovascular) suggesting MC activation, usually in association with a mild increase in serum tryptase levels. By contrast, extremely high serum tryptase levels together with the presence of C-findings are strongly suggestive of ASM. Interestingly, a significant proportion of ASM patients have a long history of an underlying and frequently misdiagnosed MIS, which can precede by years the onset of C-findings. In addition, some ISM patients experience disease progression, particularly those who show elevated serum $\beta_{2}$-microglobulin levels and D816V KIT mutation involving hematopoietic cells other than MC, including lymphoid and/or myeloid cells [4]; interestingly, multilineage involvement of hematopoiesis by the D816V KIT mutation is systematically detected in 'de novo' ASM patients. Altogether, these observations suggest that ASM and at least some ISM cases might actually represent two different stages of the same disease in which progression from an indolent to an aggressive phase is strongly associated with multilineal mutation of KIT. It should be noted that, during the very early stages of ISM, there is neither a detectable proliferation nor a significant accumulation of MC in organs/tissues, which makes early accurate diagnosis of the disease a challenge.

In recent years, the utility of the WHO classification for the diagnosis and classification of mastocytosis has been prospectively evaluated in two independent studies which included 59 [23] and 133 patients [5]. Both studies provide evidence about the existence of some false negative cases when the WHO criteria for SM are strictly used. In addition, some well-recognized categories of the disease, for example, ISMs- $[19,20]$ and WDSM [5, 14-18], are not specifically considered in the current version of the WHO classification.

Here, we review the most relevant aspects of MC biology, particularly those related to c-kit signaling and the clinical manifestations of MC disorders, as well as the methodological approaches to be applied for an objective and reproducible diagnosis and classification of SM.

\section{MAST CELL BIOLOGY AND KIT MUTATIONS}

Mast cells originate from pluripotential BM-derived hematopoietic precursors which migrate as immature cells through the blood stream. From the blood, MC home mainly into body surface tissues such as the skin, the airways, and the gastrointestinal tract, where they become fully differentiated. The stem cell factor (SCF), the ligand for the tyrosine kinase receptor c-kit [24], plays a critical role in the proliferation, maturation, and survival of MC [25], in combination with several other cytokines and growth factors such as IL4, IL-6, IL-9, IL-10, IL-12, IL-15, IL-18, nerve growth factor (NGF), thrombopoietin, and transforming growth factor (TGF)-beta [26-29, 29-33].

C-kit (CD117) is a type III receptor tyrosine kinase encoded by the human homolog of the proto-oncogene KIT, whose ligand is the SCF; SCF acts as a growth factor that dimerizes KIT molecules inducing its tyrosine kinase activity [25]. In humans, the KIT gene is coded, in the pericentromeric region of the long-arm of chromosome 4, at chromosome 4q12 [34], adjacent to the highly homologous PDGFRA gene [35].

Mutations in the KIT tyrosine kinase domain have been reported in the great majority of SM patients $(>90 \%)$ when molecular studies are performed in highly purified MC [16]. D816V is by far the most frequent mutation; however, other less common mutations have also been identified (reviewed in reference [36]) mainly in ISM lacking skin lesions [16, 20] which is of special relevance for the diagnosis of this subtype of SM. In addition, other rather infrequent KIT mutations have been described in adults which are localized at the extracellular domain (two cases of familial mastocytosis with a deletion of codon 419 of KIT [37] and the K509I KIT mutation [38], respectively), at the transmembrane domain (a case of WDSM with the F522C KIT mutation [14] and a case of familial mastocytosis with the A533D KIT mutation [39]) and at the juxtamembrane domain (a case of ASM with the V559I KIT mutation [40] and both a case of MCL [41] and a case of ISMs- (A. Garcia-Montero, unpublished data) with the V560G KIT mutation. Furthermore, other oncogenic mutations have been reported in SM, which involve the TET2 (TET oncogene family member 2) [42] and N-RAS [43] genes, and their significance in the pathogenesis of the disease still remains unknown.

Mast cells play a key role in inflammation and they are the major effector cell in allergic reactions including anaphylaxis. A wide variety of stimuli can trigger activation of MC during inflammation as well as in 
allergic and nonallergic diseases, and release of MC mediators. The most relevant triggers according to REMA's experience and literature review (see references [44-48]) are shown in Table 2. The release of MC mediators can be elicited through the cross-linking of high-affinity Fc receptors for IgE (FceRI) on the cytoplasmic membrane of normal/reactive MC $[49,50]$, Fc $\gamma$ [51-53], and complement receptors [49, 50], among other stimuli. MC synthesize and release a wide variety of preformed or newly generated mediators (reviewed in references [54, 55]), which are responsible of a great part of the symptoms and signs exhibited by mastocytosis patients (Figure 1). From a diagnostic perspective, tryptase is the most relevant MC mediator. Tryptase is a serin-protease produced by human MC which is mainly derived from the expression of two genes coded in chromosome 16p13.3: $\alpha$-tryptase and $\beta$-tryptase[56]. Notewothy, tryptase is also produced in smaller quantities by blood basophils [57]. Precursors of both $\alpha$-tryptase and $\beta$-tryptase are spontaneously released by MC, while fully processed (mature) $\beta$-tryptase is retained by the cells, mainly inside the secretory granules [58].

\section{DIAGNOSTIC PROCEDURES IN MASTOCYTOSIS}

Diagnosis of mastocytosis is mainly based on the demonstration of abnormal MC according to a combination of morphological, immunohistochemical, flow cytometric immunophenotyping, and molecular studies. Despite the relevance of the presence of multifocal dense MC aggregates denoted by its inclusion in the WHO classification as the only major criterion for SM, it should be emphasized that, at the early stages of the disease, BM MC burden is very low and, thus, MC aggregates are frequently absent in these patients. In such cases, careful evaluation of morphological, immunophenotypical, and molecular criteria are particularly mandatory for correct diagnosis and classification of the disease (Table 3).

\section{Mastocytosis in the skin}

Histomorphological examination of skin lesions plays a major role in the diagnostic work-up of the disease [3]. Because wide differences in MC distribution have been described in normal skin depending on the specific body site investigated [59], careful evaluation of MC numbers for that particular site vs. those expected under normal conditions is required for correct histological evaluation of skin lesions from subjects suspected of mastocytosis.

Stainings for skin sections should include hematoxylin and eosin (H\&E), Giemsa and also immunohistochemistry for both c-kit and tryptase. Additionally, immunostaining for $\mathrm{CD} 25$ in lesional mastocytosis skin biopsy specimens has recently emerged as a promising method to predict systemic involvement in patients with MIS [60]. Histological criteria for the diagnosis of MIS include the presence of large MC aggregates (>15 MC per cluster) or scattered MC exceeding 20 cells per microscopic high-power $(\times 40)$ field (Reviewed in reference [3]).

\section{Peripheral blood analyses}

Although peripheral blood cell counts and differential are usually normal in nonaggressive mastocytosis, weak to mild eosinophilia can be found in some cases. By contrast, cytopenia(s) and cytomorphological changes suggesting dysplasia are frequently present in ASM and MCL, as well as in SM-AHNMD. In addition, circulating MC are systematically detected in MCL and at lower percentages, in the majority of ASM cases when highly sensitive flow cytometry approaches are used for the detection of cells present at low frequencies in a sample (L. Sanchez-Muñoz, unpublished observations).

\section{Bone marrow cytomorphology and immunohistochemistry}

Bone marrow is the most appropriate site for screening systemic involvement in mastocytosis. Because BM MC are closely attached to the stroma, BM aspiration should be performed firmly and quickly from the posterior iliac crest with an $8 \mathrm{G}$ tollG biopsy needle, to obtain sufficient numbers of particles to perform BM smears, followed by a BM biopsy, the length of the BM cylinder ideally being of $\geq 2 \mathrm{~cm}$.

\section{Bone marrow cytomorphology}

Bone marrow smears must be stained with at least toluidine blue (Figure 2, panels B and C) and 
Table 2. Factors that can evoke the release of MC mediators in patients with mastocytosis

\section{Physical agents}

- Heat (frequent): use mildly warm water for bath or shower. Do not rub briskly with towel to dry off. When drying hair, use hair dryer only on warm heat - Cold (frequent)

- Pressure (frequent): traumas to scalp in patients with skin lesions in this area. Avoid Darier's sign (friction of skin lesions), this procedure can evoke a massive mast cell mediators release, specially in large lesions (mastocytomas)

- Exercise (rare)

- Endoscopies (exceptional): panendoscopy, rectoscopy, colonscopy

- Manipulation of GI system/intestines during surgery (exceptional)

\section{Emotional factors}

- Stress (frequent)

- Anxiety (frequent)

\section{Drugs and medication}

- NSAIDs* (frequent) such as aspirin (acetylsalicylic acid), mefanamic acid, butibufen, diclofenac, fenbufen, fenilbutazone, flurbiprofen, ibuprofen, indometacine, ketoprofen, ketorolac, meclofenamate, metamizole, nabumetone, naproxen, propifenazone, among other drugs

- Opioids and morphine derivatives (rare) such as morphine, codeine, buprenorphine, meperidine, dextromethorphan, dimemorphan, fentanyl, tramadol, among other drugs

- Alcoholt (rare)

- Muscle relaxants and inductors used in general anesthesial (rare)

- Local anesthetics $\ddagger$ (exceptional if amide-derivatives are used)

- Contrast media (rare)

- Interferon-alpha 2b§ (exceptional)

- Clorodeoxiadenosine (2-Cda) (exceptional)

- Hydroxyurea** (exceptional)

- Colloids (rare)

\section{Insects}

- Hymenoptera sting (frequent, particularly in ISMs-)

- Red ant (exceptional in Europe)

\section{Hormonal changes}

- Pregnancy (frequent) ††

- Menstruation (frequent)

\section{Miscellaneous}

- Infections or fever of any etiology (frequent, particularly in children)

- Teething in children (frequent)

- Vaccination (rare, except in children with DCM)
Table 2. (Continued)

Source: REMA, specific protocols in risk situations in patients with mastocytosis, updated 2011.

*The frequency of MC-mediators release related to NSAIDs in patients from the REMA is $2 \%$ in children and $14 \%$ in adults [47].

tThe frequency of MC-mediators release symptoms triggered by alcohol in patients from the REMA is $<1 \%$ (REMA, unpublished data).

Among 73 adult patients from the REMA who underwent general anaesthesia, three suffered severe MC-mediators release symptoms (two cardiorrespiratory arrests, and one coagulopathy with hypovolemic shock), the specific protocols in risk situations in mastocytosis were not followed in such three cases (REMA, unpublished); regarding pediatric mastocytosis, 17 children underwent general anaesthesia, and no severe mast-cell mediators release episodes were reported (REMA, unpublished data).

¥No MC-mediators related symptoms were recorded in 850 BM biopsies and 1,235 cutaneous biopsies performed in patients from the REMA between 1984 and 2006 using adequate premedication (REMA, unpublished data); in eight of these cases who had previous history of anaphylaxis induced by stress, the BM biopsies were performed in the ICU with premedication, local anaesthesia and sedation.

$\S N o$ MC-mediators related symptoms were reported in 23 cases from the REMA who underwent interferon therapy (REMA, unpublished data); in all of these cases, antimediator premedication was used according to the REMA's specific protocols, and the three initial doses were administered at an ICU.

- Only one case has been reported so far (J. Sheik, Beth Israel Hospital, Harvard Medical School, personal communication, September 2002).

**It has been seen in one patient from the REMA (REMA, unpublished data).

††The frequency of pregnancies with a worsening of MC-mediators symptoms during pregnancy ranges from $22 \%$ [48] to $45 \%$ [44].

MC, mast cell; GI, gastrointestinal; NSAIDs, non-steroidal antiinflammatory drugs; REMA, Spanish Network on Mastocytosis; ISMs-, indolent systemic mastocytosis in the absence of skin lesions; DCM, diffuse cutaneous mastocytosis; BM, bone marrow; ICU, Intensive Care Unit.

May-Grünwald-Giemsa (MGG) (Figure 2, panels A, D and E) for cytomomorphological evaluation of MC. MC can be easily identified in toluidine blue-stained BM smears as red-purple elements over a blue background; the toluidine blue stain allows an overall 


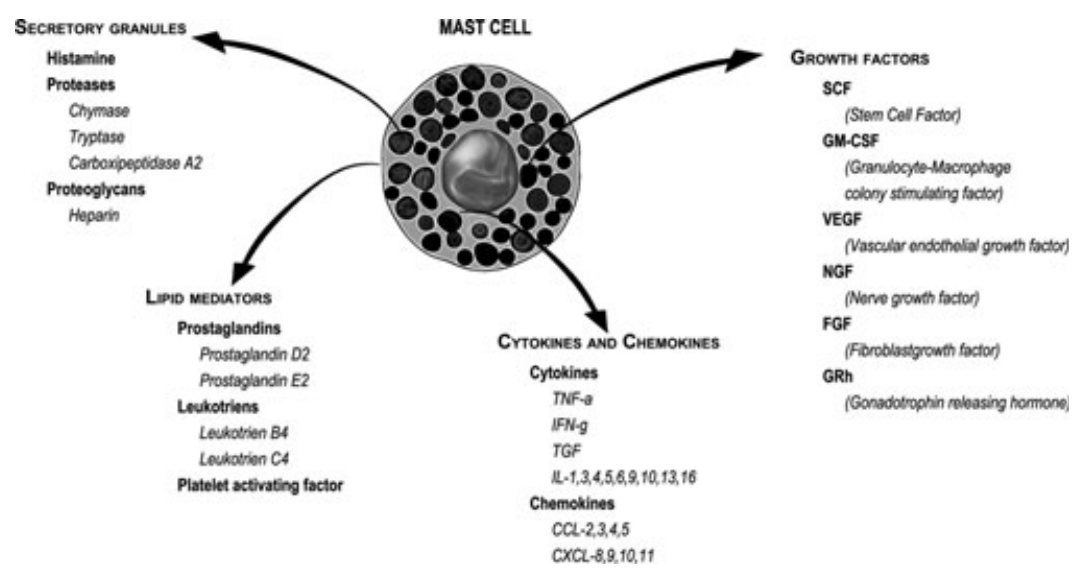

Figure 1. Main mast cell mediators (reviewed in references [54, 55]). estimation of the degree of BM infiltration by MC and, therefore, also an estimation of the amount of sample needed to be further processed for immunophenotyping and molecular analyses. Interestingly, BM MC aggregates (major WHO criterion for SM) are frequently detected in BM smears containing enough BM particles [5]. In turn, MGG stain allows a better cytomorphological characterization of MC as well as the identification of eosinophilia, dysplastic features, and other morphological features suspicious of a coexisting hematological malignancy. It should be emphasized that for correct cytomorphological evaluation of MC, this should be performed outside BM particles. The most commonly described MC atypias in SM are spindle-shaped MC, eccentric and oval nucleus, hypogranulation, abnormal granule distribution, and granule fusion phenomena; however, in some cases, round or poligonal MC coexist with fusiform shapes or they even predominate [5]. Such atypical MC morphological features can also be seen in disease conditions other than mastocytosis, for example, a subset of hypereosinophylic syndromes (HES) with the FIPIL1PDGFRA fusion gene, elevated serum tryptase, and CD25+ MC lacking somatic KIT mutations [12]. In a subgroup of patients, particularly in ASM and MCL cases showing higher degree of BM infiltration, MC also show immature cytological features such as a wide size heterogeneity, multilobed nuclei (promastocytes), or a poor-differentiated morphology (metachromatic blasts) $[5,8]$. In contrast, among WDSM cases, BM MC typically exhibit a mature appearance, an increased size, and a round shape, with round nucleus and a fully granulated cytoplasm with relatively frequent degranulation phenomena (vacuoles)
[18]. However, these findings are associated but not fully specific of WDSM and they must be considered in the overall clinical, immunophenotypical, and molecular setting of the patient, to diagnose or rule out WDSM.

In MCL, which is a rare variant of mastocytosis characterized by a rapidly progressive disease with multiorgan involvement and a very poor pronosis, highly atypical MC (e.g., metachromatic blasts and promastocytes) can be seen in both BM and peripheral blood smears. Main cytomorphological characteristics of these MC include the presence of bior polylobed nuclei, a high nuclear-to-cytoplasmic ratio, smooth chromatin, prominent nucleoli and usually few scattered metachromatic granules, which might difficult their identification as MC-lineage cells.

\section{Bone marrow histopathology}

The presence of multifocal, dense aggregates of $\geq 15$ MC in tissue sections from biopsy specimens from $\mathrm{BM}$ and/or other extracutaneous organs is highly specific of mastocytosis, and they are constantly observed in all poor-prognosis categories of the disease (ASM, MCL, and SM-AHNMD); nevertheless, around $20 \%$ of all ISMs+ cases and up to $35 \%$ of ISMs- lack such aggregates $[4,5,20]$, these cases frequently corresponding to patients that show both lower percentages of BM MC by flow cytometry and lower serum baseline tryptase levels. This translates into a lower sensitivity of the WHO major criterion for the diagnosis of SM at the early stages of the disease [5]. 
Table 3. Most relevant laboratory hematology techniques required for the diagnosis and classification of mastocytosis and their clinical utility

\begin{tabular}{|c|c|c|c|}
\hline Method & Technical issues & Information provided & Diagnostic utility \\
\hline \multirow[t]{4}{*}{ Cytology } & Smears with BM particles & $\begin{array}{l}\text { MC numbers } \\
\text { (semi-quantitative) }\end{array}$ & $\begin{array}{l}\text { Major criterion: MC } \\
\text { aggregates }\end{array}$ \\
\hline & $\begin{array}{l}\text { Stainings: toluidine blue, MGG, } \\
\text { other (if associated } \\
\text { diseases are suspected) }\end{array}$ & MC morphology & $\begin{array}{l}\text { Minor criterion: Abnormal } \\
\text { MC morphology }\end{array}$ \\
\hline & & MC aggregates & Associated diseases \\
\hline & & Overall morphology & \\
\hline \multirow[t]{5}{*}{$\begin{array}{l}\text { Histology and } \\
\text { immunohistochemistry }\end{array}$} & BM cylinder $>2 \mathrm{~cm}$ in length & Cellularity & $\begin{array}{l}\text { Major criterion: } \mathrm{MC} \\
\text { aggregates }\end{array}$ \\
\hline & $\begin{array}{l}\text { Stainings: H\&E, Giemsa, } \\
\text { tryptase, CD 117, CD25 }\end{array}$ & MC morphology & $\begin{array}{l}\text { Minor criterion: Abnormal } \\
\text { MC morphology }\end{array}$ \\
\hline & & MC aggregates & Associated diseases \\
\hline & & BM fibrosis & \\
\hline & & Bone sclerosis & \\
\hline \multirow[t]{4}{*}{$\begin{array}{l}\text { Flow cytometry } \\
\text { immunophenotyping }\end{array}$} & Sample containing BM particles & MC numbers & $\begin{array}{l}\text { Minor criterion: expression } \\
\text { of CD25 and/or CD } 2\end{array}$ \\
\hline & $\begin{array}{l}\text { Monoclonal antibody clones, } \\
\text { fluorochrome reagents } \\
\text { and combinations should be } \\
\text { carefully selected }\end{array}$ & $\begin{array}{l}\text { Expression of CD25 and } \\
\text { other aberrant markers } \\
\text { by MC }\end{array}$ & $\begin{array}{l}\text { Immunophenotypical } \\
\text { pattern of MC: Mature } \\
\text { resting } v s . \text { activated } v s . \\
\text { immature }\end{array}$ \\
\hline & Apply specific gating strategies & $\begin{array}{l}\text { Imunophenotypical } \\
\text { characteristics of other } \\
\text { cell lineages }\end{array}$ & \\
\hline & $\begin{array}{l}\text { In cases with very low MC } \\
\text { numbers acquire } \\
\text { enough number of cells }\end{array}$ & & \\
\hline \multirow[t]{7}{*}{ Molecular biology } & $\begin{array}{l}\text { DNA or RNA is adequate sample } \\
\text { for PCR-based techniques }\end{array}$ & $\begin{array}{l}\text { Presence vs. absence } \\
\text { of KIT mutation }\end{array}$ & $\begin{array}{l}\text { Minor criterion: D816V } \\
\text { KIT mutation }\end{array}$ \\
\hline & $\begin{array}{l}\text { Study of KIT mutations in } \\
\text { highly purified MC and other } \\
\text { hematopoietic cell compartments } \\
\text { should be performed }\end{array}$ & $\begin{array}{l}\text { KIT mutation restricted } \\
\text { to MC vs. multilineal }\end{array}$ & $\begin{array}{l}\text { Mutational pattern of MC } \delta \\
\text { other cell compartments } \\
\text { with prognostic impact }\end{array}$ \\
\hline & $\begin{array}{l}\text { Purify using FACs-sorting } \\
\text { procedures }\end{array}$ & $\begin{array}{l}\text { In SM-AHNMD } \\
\text { information of the KIT } \\
\text { mutational status in } \\
\text { both neoplasias }\end{array}$ & $\begin{array}{l}\text { Demonstration of clonality } \\
\text { by HUMARA in women } \\
\text { with KIT mutation-negative } \\
\text { MC }\end{array}$ \\
\hline & $\begin{array}{l}\text { Purify at least MC, neutrophils, } \\
\text { monocytes and lymphocytes }\end{array}$ & & \\
\hline & Investigate clonality by the & & \\
\hline & HUMARA test in women & & \\
\hline & lacking KIT mutations & & \\
\hline
\end{tabular}

Source: Escribano et al. [6].

BM, bone marrow; MC, mast cells; MGG, May-Grünwald-Giemsa; H\&E, hematoxylin and eosin; DNA, deoxyribonucleic acid; RNA, ribonucleic acid; PCR, polymerase chain reaction; FACs, fluorescence-activated cells; HUMARA, human androgen receptor; SM-AHNMD, systemic mastocytosis with an associated clonal haematological non-mast cell lineage disease.

In c-kit (Figure 2, panels $\mathrm{F}$ and $\mathrm{G}$ ) and/or tryptasestained (Figure 2, panels I and J) BM sections, MC can be easily identified as spindle-shaped or round cells, or an admixture of both [5]. As for skin sections, CD25 (Figure 2, panel H) is also a useful immunohistochemical marker to confirm the neoplastic nature of 

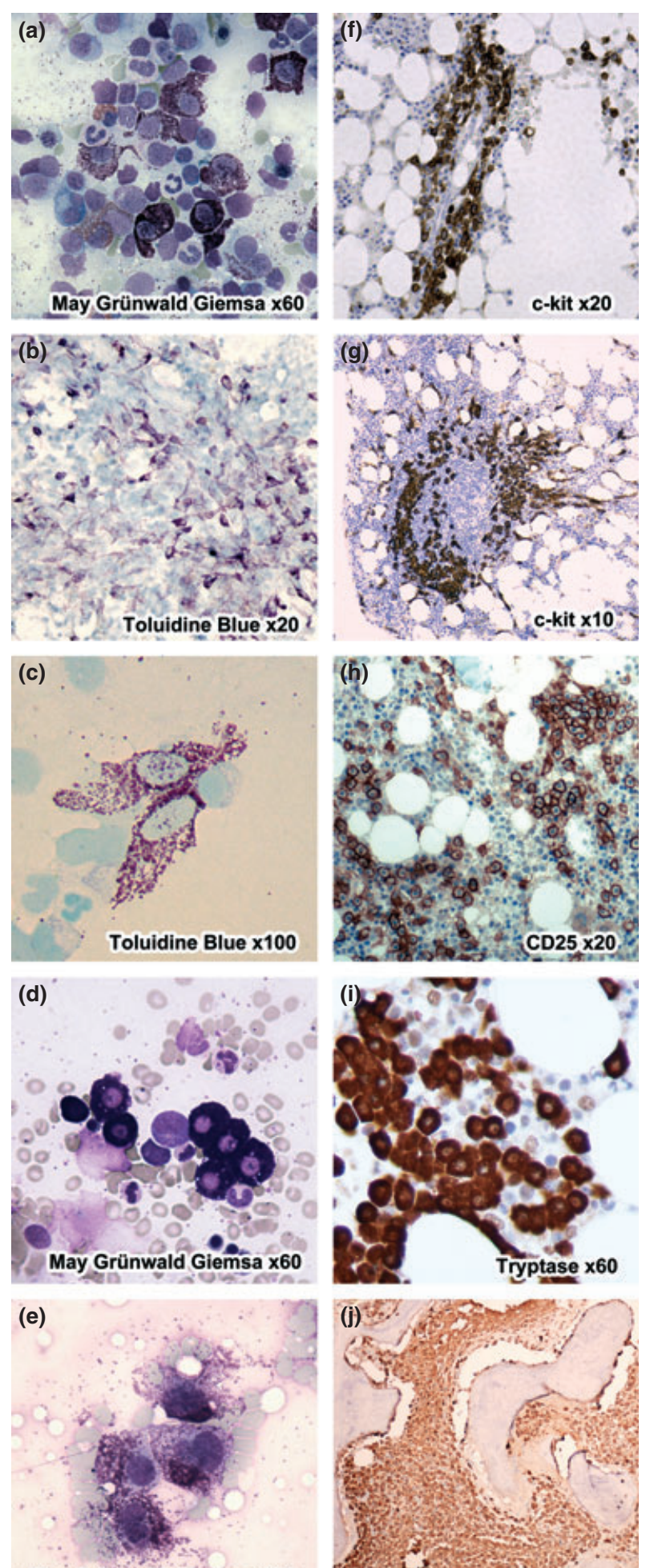

May Grünwald Giemsa x100
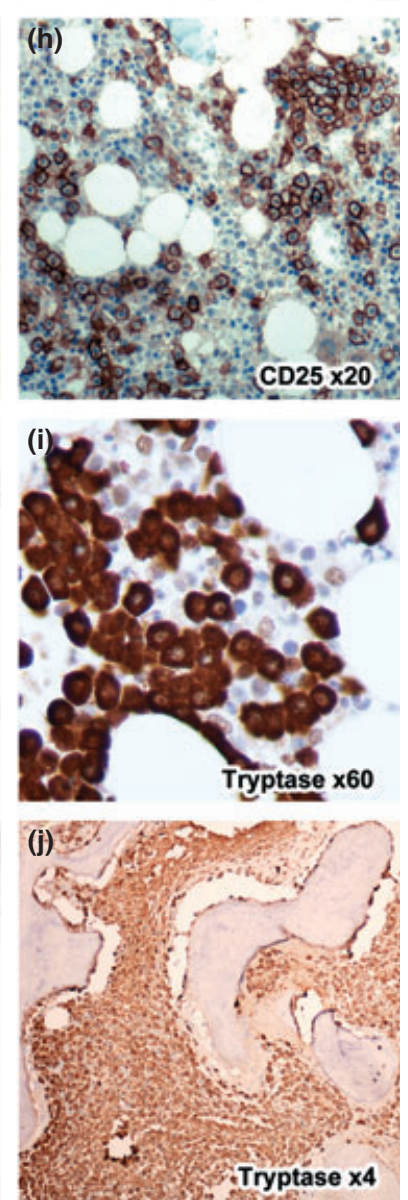

MC in cases showing compact MC aggregates [61, 62]; nevertheless, this staining has a more limited utility in cases lacking $\mathrm{MC}$ aggregates in which the distinction between abnormal MC and CD25-positive T-lymphocytes becomes a challenge, and in CD25-negative WDSM subjects. In addition, expression of CD30 (also known as Ki-l antigen) has been reported to be a potentially useful prognostic marker in mastocytosis because this marker is strongly expressed by MC from poor-prognosis categories of mastocytosis (ASM and MCL), while its expression is missing or low in most ISM cases [63; 64].

Depending on the number and distribution of MC in the BM, different histological patterns can be observed (reviewed in reference [65]. Accordingly, whereas ASM and MCL cases systematically show a dense, diffuse MC infiltration, ISM may have different patterns of BM involvement ranging from an increase of interstitial MC without evidence of compact MC aggregates, to focal, dense MC aggregates with or without a diffuse component. Interestingly, these focal MC aggregates are commonly paratrabecular in location, which might facilitate the frequent development of bone alterations in patients with ISM. Other relatively common findings among cases from all subtypes of SM include focal or

Figure 2. Images of bone marrow (BM) smears (panels a to e) and BM sections (panels $\mathrm{f}$ to $\mathrm{j}$ ) from several systemic mastocytosis (SM) patients. (a) High-power view showing fusiform mast cells (MC) together with round and oval MC from a case of indolent SM (ISM). (b) Low-power view showing a marked increase of atypical MC from an aggressive SM (ASM) patient. (c) High-power view showing two spindle-shaped MC. (d) High-power view showing round, fully granulated MC from a case of well-differentiated SM (WDSM). (e) High-power view showing morphologically poor-differentiated MC, some of which display two nuclei (promastocytes) from a case of ASM. (f) Low-power view showing a perivascular infiltrate of MC from a case of ISM. (g) Lowpower view showing a large lymphoid aggregate admixed with MC from a case of ISM. (h) Lowpower view showing CD25-positive MC from a case of ISM. (i) High-power view showing round, fully granulated, tryptase-positive MC from a case of WDSM. (j) Low-power view showing a dense, diffuse MC infiltration from a case of ASM. 
diffuse eosinophilia and lymphoid aggregates usually surrounding or admixed with MC clusters. The presence of such lymphoid aggregates has been found in $44 \%$ of all SM cases in our series (L. Escribano, unpublished data) and they contain both mature $\mathrm{T}$ and $\mathrm{B}$ cells [66], but its significance remains still unknown. By contrast, pronounced BM fibrosis and/or osteosclerosis are more frequently associated with poor-prognosis categories with high MC burden.

\section{Multiparameter flow cytometry immunophenotypical analysis of mast cells}

Flow cytometry is the preferred method for the evaluation of $\mathrm{CD} 25$ and $\mathrm{CD} 2$ expression on BM MC from subjects suspected of mastocytosis, particularly among cases with low MC numbers. Because of its great sensitivity, flow cytometry immunophenotypical analysis of BM MC is currently considered the gold standard for the identification of aberrant MC. MC from BM samples from both normal subjects and mastocytosis patients can be specifically identified and accurately enumerated using multiparameter flow cytometry based on their unique light scatter properties, dim CD45 and strong CD117 expression [67] (Figure 3). The technical aspects as well as the critical parameters related to MC identification, enumeration, and immunophenotyping have been extensively reviewed elsewhere $[13,68-71]$.

In addition, flow cytometric immunophenotype of BM MC from SM patients has been extensively investigated [69, 72-78]. In contrast to normal MC, MC from mastocytosis aberrantly express high levels of the low affinity IL-2 receptor $\alpha$-chain (CD25) [13, 74, 79], except in WDSM [5, 14, 17, 18]; in turn, expression of CD2 is not detected in a variable percentage of SM cases $[17,80,81]$. Based on these findings, it has recently been proved that $\mathrm{CD} 25$ expression is a more reliable diagnostic criterion for SM other than WDSM compared with the current CD25 and/or CD2 expression, proposed by the WHO [81]. Apart from the aberrant expression of $\mathrm{CD} 25$ and $\mathrm{CD} 2, \mathrm{BM}$ MC from SM display other immunophenotypical alterations which have been extensively described and reviewed in the literature. Noteworthy, clonal MC from WDSM typically display overexpression of cytoplasmic enzymes such as tryptase and carboxypeptidase, despite they do not show aberrant expression of CD25 and CD2 [17, 80]. Distinct diagnostic categories of SM are associated with unique immunophenotypic features which also reflect the multilineage involvement of BM hematopoiesis [13, 17, 67, 69-74, 76, 82-85]. Accordingly, three different maturation-associated immunophenotypic profiles have been recently identified in BM MC from patients with SM [17] which correlate with prognostic and molecular subtypes of the disease (Figure 3): i) an activated MC phenotype, typical of the majority of ISM patients, which is characterized by aberrant expression of CD25 and CD2 together with an abnormally increased expression of the CD63, CD69, and CD203c proteins and both the CD64 high-affinity FCIgG receptor and the HLA-DR MHC class II molecule; ii) a mature resting MC phenotype, detected in WDSM, which consists of lack of expression of both $\mathrm{CD} 25$ and $\mathrm{CD} 2$, a normal profile for activation-associated markers, strong expression of CD117 and FceRI; and iii) an immature immunophenotypic profile associated with the poor-prognosis categories of SM, defined by the aberrant expression of CD25 usually in the absence of CD2, associated with decreased expression of maturation-associated markers (e.g., CDl17, FcERI) and increased positivity for CD123, HLA-DQ, and HLA-DR.

\section{Molecular assays}

\section{Detection of KIT mutations}

Multiple molecular methods have been used to specifically detect the D816V KIT mutation in SM patients [16, 86-93]. Reverse transcriptase (RT) polymerase chain reaction (PCR) assays (mRNA/cDNA-based methods) $[86,88,92]$ are very sensitive for the detection of the KIT mutation in MC admixed with other cells in the sample at rather low frequencies (e.g., $\mathrm{BM}$, blood and spleen), because MC together with a small subset of basophils and NK-cells are the only mature hematopoietic cells expressing KIT mRNA within these samples. Among the genomic (g)DNAbased methods $[16,86-88,90,92,93]$, the most straight forward and simple approach would be those based in direct sequencing of the mutated DNA locus [86], but they have very low sensitivity because the D816V KIT mutation is usually heterozygous and mutated MC are mixed with huge amounts of other (ususally nonmutated) hematopoietic (e.g., BM, 

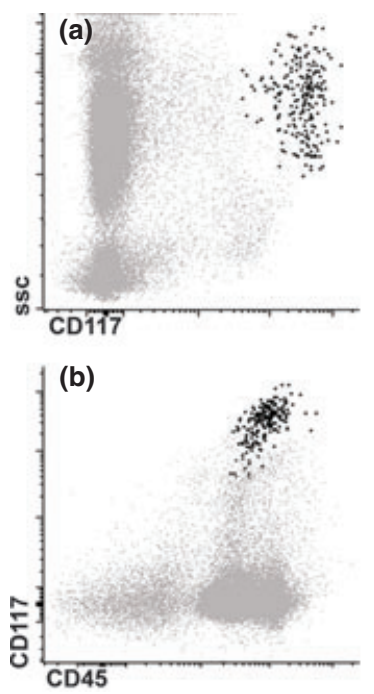
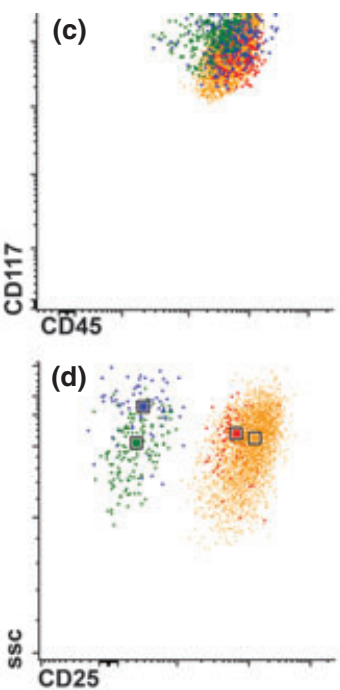
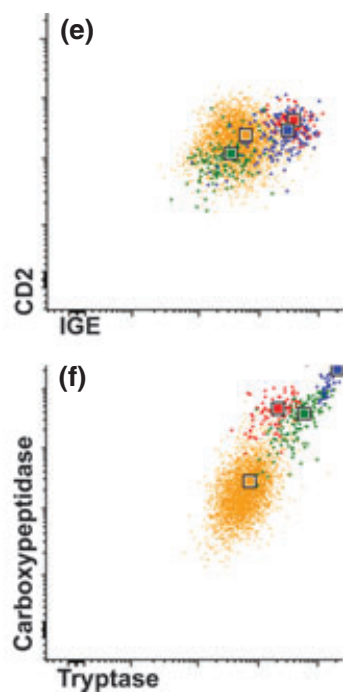

Figure 3. Mast cell identification by flow cytometry (black dots) based on light scatter parameters and on the expression of CD45 and CD117 (Panels a and b). Overlayed representative immunophenotypic profiles of mast cells from healthy adults (green dots), indolent systemic mastocytosis (red dots), aggressive systemic mastocytosis (orange dots) and well-differentiated systemic mastocytosis (blue dots). Data sets representative of each group of subjects were fused using Infinicyt software (Cytognos SL, Salamanca, Spain) and presented together. The squared dots represent medians of each data set (Panels c to f).

blood, spleen) or epithelial (skin) cells carrying wild-type KIT. An improved sensitivity has been reached either by enhancing mutated allele frequencies using digestion steps by specific restriction endonucleases and PCR amplification [86, 91] or by using specific probes that selectively block amplification of the wild-type sequence [87]. The later PNA-mediated wild-type blocking method has the advantage of allowing detection of the D816V KIT mutation as well as other rare KIT mutations involving the TK2 regulatory domain at codons 815-819 [16, 87]. Other gDNA-based assays using allele-specific competitive blockers of the mutated sequences and traditional [89, 90] or quantitative (q)PCR [93] assays also have been shown to be associated with a very good sensitivity $(<1 \%$ or $<0.03 \%$, respectively).

Independently of the method used for the KIT mutation assay, all recent studies on large series of SM patients have confirmed that D816V KIT mutation is as frequent in ISM as in ASM [16, 91], with marked differences in the reported frequencies (range: approximately $80 \%$ to approximately $100 \%$ ) depending on whether the study was performed in whole BM samples [91] or in highly purified BM MC [16]. Such studies have ruled out previous assumptions about the potential association of the D816V KIT mutation with the more severe forms of SM (for review see [36]).

Interestingly, we have recently shown that, while in most ISM cases $(73 \%)$ the D816V KIT mutation is restricted to $\mathrm{MC}$, most ASM cases (approximately $98 \%$ ) carry the KIT mutation in other myeloid and even lymphoid cell compartments [16]. In addition, multilineage involvement of hematopoietic cells by the KIT mutation has also been associated with a shorter progression-free survival and a worse prognosis of the disease [4].

Different approaches have been applied to detect KIT mutations in enriched or purified cell compartments, namely microdissection of archived formalinfixed paraffin-embedded BM or skin biopsies [87, 94, 95], and both immunomagnetic [88, 92] and/or fluorescence-activated cell sorting $[4,16,88]$ of BM and blood samples. Currently, in SM cases carrying the KIT mutation in BM MC, the REMA recommends to perform the KIT mutation assays in at least one highly purified population (>97\%) of myeloid cells (e.g., BM monocytes and/or maturing neutrophils) and a population of lymphoid cells (e.g., total lymphocytes or 
CD19+ cells), apart from MC [4, 5]. Of note, it is also important to rule out cross-contamination of the purified cell populations by mutated MC, because molecular methods associated with a very high sensitivity $(<1 \%)$ could lead to false positive results whenever low proportions of mutated MC are present in the sample containing the purified non-MC population. As virtually all mature myeloid and lymphoid hematopoietic cells do not express the c-kit receptor, only those methods targeting gDNA [16, 86-90, 93] are informative for the detection of the presence of the KIT mutations in mature non-MC hematopoietic cells. Nevertheless, it should be noted that in SM with multilineal involvement by the D816V KIT somatic mutation, the disease emerges from early pluripotent mutated stem cells that coexist with normal stem cells, and consequently, each hematopoietic population (e.g. the monocytes) typically consists of a mixture at different proportions of mutated and nonmutated cells [96]. Thus, the selected method should have enough sensitivity to detect relatively low numbers of mutated cells. In line with this, some new gDNA-based methods have been described which are associated with a good sensitivity $(<0.03 \%)$ and quantitative (qPCR) estimation of the percentage of mutated allele dosage [93] in whole peripheral blood (PB) samples from aleukemic SM patients.

\section{Detection of mast cell clonality}

For those rare SM cases which lack KIT mutations (e.g., most WDSM and some ISMs-), MC clonality can be confirmed in women through the analysis of the pattern of inactivation of polymorphic genes coded in the human chromosome X (e.g., PCR-based human androgen receptor allele - HUMARA - assay) $[97,98]$. Such assays exploit the random pattern of inactivation of chromosome $\mathrm{X}$ in individual hematopoietic stem cells. However, it should be emphasized that also the HUMARA test must be performed in gDNA obtained from highly purified (>90\%) MC, using gDNA obtained from, for example, total BM or $\mathrm{PB}$, as a control [20]. Because most WDSM patients are women, the HUMARA assay can be applied in the vast majority of patients with this rare variant of the disease, being an invaluable tool to confirm the clonal origin of BM MC and the systemic nature of the disease [5]. Despite the overall utility of these tech- niques, they are typically not available in many routine laboratories and should be performed in experienced reference centers.

\section{Biochemical markers}

\section{Serum tryptase}

The presence of total serum tryptase levels persistently $>20 \mu \mathrm{g} / \mathrm{L}$ is one of the minor diagnostic WHO criteria for SM. The tryptase test recommended for such measurements in routine laboratory diagnostics is a fluoroimmunoenzyme assay which detects both the $\alpha$ and the $\beta$ tryptase subunits, to yield total serum tryptase levels (CAP, Phadia Diagnostics, Uppsala, Sweden). In mastocytosis patients, a correlation between serum total tryptase levels (sBt) and BM involvement has been resported [10]. Similarly, sBt levels have also been associated with different categories of the disease [99-101] (reviewed in references [99, 100, 102]). Furthermore, elevated tryptase levels are also found in patients with diffuse bone sclerosis [4, 5, 103], chronic urticaria [104], clonal myeloid malignancies [9, 11, 12, 105], and advanced kidney disease [106], among other disorders. To increase the sensitivity of $\mathrm{sBt}$ in SM, it has been recently proposed to lower the $20 \mu \mathrm{g} / \mathrm{L}$ sBt cut-off [107], in line with our own experience and data.

Most interestingly, recent data based on a series of 74 patients with ISM who have been prospectively followed up for a median of close to 8 years show that those patients who experience progressively increased in sBt levels over time more likely show disease progression, while in those who have stable sBt levels, the disease is kept under an indolent controlled form (Matito A, unpublished data).

\section{Serum $\beta_{2}$-microglobulin and $\mathrm{LDH}$}

In a previous prospective study carried out in a large series of adult ISM cases, we reported that apart from the presence of multilineal D816V KIT mutation, the detection of increased serum $\beta_{2}$-microglobulin levels at diagnosis was an independent predictor of transformation into a more aggressive form of the disease [4]. More recently, it has been reported that the combination of increased $\beta_{2}$-microglobulin and decreased LDH levels was closely linked to ASM patients, while 
coexistence of both parameters was only found in a minority of ISM cases [5].

\section{DISEASE MONITORING AND FOLLOW-UP}

Disease monitoring in nonaggressive cases should include a complete clinical and physical work-up together with a routine peripheral blood count and differential, routine biochemistry, sBt and $\beta_{2}$-microglobulin. In addition, imaging studies including abdominal ultrasonography and/or computed tomography scan must be periodically performed (e.g., every 2 years) in cases with multilineal KIT mutations.

Regarding the bone, dual energy X-ray absorptiometry should be performed every 1.5-2 years as a part of therapy response assessment in cases with bone mass loss under treatment, whereas every 4-5 years in patients with normal bone density at diagnosis, unless additional risk factors for bone mass loss are present (e.g., menopausia or chronic therapy with corticosteroids). Skeletal X-ray survey and/or magnetic resonance imaging should be only performed during follow-up in selected patients who develop bone pain or clinical/laboratory data suggesting disease progression; in these later cases, a new BM study must be also performed.

\section{CONCLUSION}

Major advances have been made in the last decades in the understanding of MC disorders, leading to welldefined consensus diagnostic criteria for mastocytosis. These criteria include several disease features which are directly related to the neoplastic nature of MC (e.g., the cytological, immunohistochemical, immunophenotypic and molecular characteristics of MC), together with findings that indirectly reflect an estimation of the increased MC burden (e.g., elevated serum tryptase levels). However, more recent data indicate that despite the great clinical utility of the current WHO diagnostic criteria for SM, their role for the diagnosis of new variants of the disease specifically not recognized in the WHO classification (e.g., WDSM) or SM patients who present at very early stages of the disease with low MC burden is still limited. Accumulating evidence also suggests a continuous spectrum of disorders with a close relationship between the progression of ISM into more agressive forms of the disease and the presence of specific disease features such as an immature immunophenotypic profile of $\mathrm{MC}$, multilineal involvement of BM hematopoietic cells by the KIT mutation and increased $\beta_{2}$-microglobulin levels at diagnosis. Because of this, highly sensitive and specific diagnostic procedures (e.g., multiparameter flow cytometry immunophenotyping of BM MC and molecular analysis of the D816V KIT mutation in highly purified BM MC and other purified compartments of hematopoietic cells) should be routinely performed for diagnostic/prognostic purposes in experienced reference centers during the diagnostic work-up of patients with mastocytosis, to avoid false negative results and provide a more precise estimation of the actual prognosis for individual patients. When these procedures are not available, evaluation of surrogate markers (e.g., elevated serum $\beta_{2}$-microglobulin levels at diagnosis and monitoring of sBt levels over time) may contribute to an indirect estimation of the risk of disease progression. Despite this, refined criteria for improved prognostic stratification of SM are still needed, particularly for cases diagnosed at early stages of the disease with very low MC burden.

\section{FUNDING}

This work was supported by grants from the Fondo de Investigaciones Sanitarias (FIS) of the Instituto de Salud Carlos III, Ministerio de Economia y Competitividad of Spain (PS09/00032 and PI11/02399, FEDER); Fundación Sociosanitaria de Castilla-La Mancha (2007/36, 2010/008 y G-2010/C-002); Fundación Española de Mastocitosis (FEM 2010); Junta de Castilla y León (Grant SAN/103/2011); BioB-HVS supported by grant of RETICS RD09/0076/00074 (Toledo, Spain) and RETICS RD06/0020/0035, (FEDER) from the Instituto de Salud Carlos III, Ministerio de Economia y Competitividad of Spain. 


\section{REFERENCES}

1. Horny HP, Metcalfe DD, Bennet JM, Bain BJ, Akin C, Escribano L, Valent P. Mastocytosis. In: WHO Classification of Tumours of Haematopoietic and Lymphoid Tissues. Swerdlow SH, Campo E, Harris NL, Jaffe ES, Pileri SA, Stein $\mathrm{H}$, Thiele J, Vardiman JW (eds). Lyon: IARC; 2008: 54-63.

2. Valent P, Horny HP, Escribano L, Longley BJ, Li CL, Schwartz LB, Marone G, Núñez R, Akin C, Sotlar K, Sperr W, Wolff K, Brunning RD, Parwaresch RM, Austen KF, Lennert AK, Metcalfe D, Vardiman JW, Bennet JM. Diagnostic criteria and classification of mastocytosis: a consensus proposal. Leuk Res 2001;25:603-25.

3. Valent $\mathrm{P}$, Akin C, Escribano L, Fodinger M, Hartmann K, Brockow K, Castells M, Sperr WR, Kluin-Nelemans HC, Hamdy NA, Lortholary O, Robyn J, van DJ, Sotlar K, Hauswirth AW, Arock M, Hermine O, Hellmann A, Triggiani M, Niedoszytko M, Schwartz LB, Orfao A, Horny HP, Metcalfe DD. Standards and standardization in mastocytosis: consensus statements on diagnostics, treatment recommendations and response criteria. Eur J Clin Invest 2007;37:435-53.

4. Escribano L, Alvarez-Twose I, SanchezMunoz L, Garcia-Montero A, Nunez R, Almeida J, Jara-Acevedo M, Teodosio C, Garcia-Cosio M, Bellas C, Orfao A. Prognosis in adult indolent systemic mastocytosis: a long-term study of the Spanish Network on Mastocytosis in a series of 145 patients. J Allergy Clin Immunol 2009;124:514-21.

5. Sanchez-Munoz L, Alvarez-Twose I, GarciaMontero AC, Teodosio C, Jara-Acevedo M, Pedreira CE, Matito A, Morgado JM, Sanchez ML, Mollejo M, Gonzalez-de-Olano D, Orfao A, Escribano L. Evaluation of the WHO criteria for the classification of patients with mastocytosis. Mod Pathol 2011a:24:1157-68.

6. Escribano L, Garcia-Montero A, SanchezMunoz L, Teodosio C, Alvarez-Twose I, Jara-Acevedo M, Morgado JM, Almeida J, Orfao A. Diagnosis of adult mastocytosis: role for bone marrow analysis. In: Laboratory Hematology Practice. Kottke-Marchant $\mathrm{K}$, Davis BH (eds). London: Wiley-Blackwell; 2012: 388-98, in press.

7. Horny HP, Sillaber C, Menke D, Kaiserling E, Wehrmann M, Stehberger B, Chott A, Lechner K, Lennert K, Valent P. Diagnostic value of immunostaining for tryptase in patients with mastocytosis. Am J Surg Pathol 1998;22:1132-40.

8. Sperr W, Escribano L, Jordan JH, Schernthaner GH, Kundi M, Horny HP, Valent P. Morphologic properties of neoplastic mast cells: delineation of stages of maturation and implication for cytological grading of mastocytosis. Leuk Res 2001a;25:529-36.

9. Sperr WR, Jordan JH, Baghestanian M, Kiener HP, Samorapoompichit P, Semper H, Hauswirth A, Schernthaner GH, Chott A, Natter S, Kraft D, Valenta R, Schwartz LB, Geissler K, Lechner K, Valent P. Expression of mast cell tryptase by myeloblasts in a group of patients with acute myeloid leukemia. Blood 2001b;98:2200-9.

10. Sperr WR, Jordan JH, Fiegl M, Escribano L, Bellas C, Dirnhofer S, Semper H, Simonitsch-Klupp I, Horny HP, Valent P. Serum tryptase levels in patients with mastocytosis: correlation with mast cell burden and implication for defining the category of disease. Int Arch Allergy Immunol 2002b;128:136-41.

11. Sperr WR, Stehberger B, Wimazal F, Baghestanian M, Schwartz LB, Kundi M, Semper H, Jordan JH, Chott A, Drach J, Jäger U, Geissler K, Greschniok A, Horny HP, Lechner K, Valent P. Serum tryptase measurements in patients with myelodysplastic syndromes. Leuk Lymphoma 2002c;43:1097-105.

12. Klion AD, Noel P, Akin C, Law MA, Gilliland DG, Cools J, Metcalfe DD, Nutman TB. Elevated serum tryptase levels identify a subset of patients with a myeloproliferative variant of idiopathic hypereosinophilic syndrome associated with tissue fibrosis, poor prognosis, and imatinib responsiveness. Blood 2003;101:4660-6.

13. Escribano L, Diaz-Agustin B, López A, López RN, García-Montero A, Almeida J, Prados A, Angulo M, Herrero S, Orfao A, Spanish NM. Immunophenotypic analysis of mast cells in mastocytosis: when and how to do it. Proposals of the Spanish network on mastocytosis (REMA). Cytometry B Clin Cytom 2004;58:1-8.

14. Akin C, Fumo G, Yavuz AS, Lipsky PE, Neckers L, Metcalfe DD. A novel form of mastocytosis associated with a transmembrane c-kit mutation and response to imatinib. Blood 2004b;103:3222-5.

15. Akin C, Escribano L, Núñez R, García-Montero A, Angulo M, Orfao A, Metcalfe DD Well-differentiated systemic mastocytosis: a new disease variant with mature mast cell phenotype and lack of codon 816 c-kit mutations. J Allergy Clin Immunol 2004a;113:S327.

16. Garcia-Montero AC, Jara-Acevedo M, Teodosio C, Sanchez ML, Nunez R, Prados A, Aldanondo I, Sanchez L, Dominguez M, Botana LM, Sanchez-Jimenez F, Sotlar K, Almeida J, Escribano L, Orfao A. KIT mutation in mast cells and other bone marrow haematopoietic cell lineages in systemic mast cell disorders. A prospective study of the Spanish Network on Mastocytosis (REMA) in a series of 113 patients. Blood 2006; 108:2366-72.

17. Teodosio C, Garcia-Montero AC, Jara-Acevedo M, Sanchez-Munoz L, Alvarez-Twose I, Nunez R, Schwartz LB, Walls AF, Escribano L, Orfao A. Mast cells from different molecular and prognostic subtypes of systemic mastocytosis display distinct immunophenotypes. J Allergy Clin Immunol 2010;125:719-26.

18. Alvarez-Twose I, González P, Morgado JM, Jara-Acevedo M, Sánchez-Muñoz L, Matito A, Mollejo M, Orfao A, Escribano L. Complete response after imatinib mesylate therapy in a patient with well-differentiated systemic mastocytosis. J Clin Oncol 2012, Epub ahead of print.

19. Bonadonna P, Perbellini O, Passalacqua G, Caruso B, Colarossi S, Dal FD, Castellani L, Bonetto C, Frattini F, Dama A, Martinelli G, Chilosi M, Senna G, Pizzolo G, Zanotti $\mathrm{R}$. Clonal mast cell disorders in patients with systemic reactions to Hymenoptera stings and increased serum tryptase levels. J Allergy Clin Immunol 2009;123:680-6.

20. Alvarez-Twose I, Gonzalez de Olano D, Sanchez-Munoz L, Matito A, Esteban-Lopez MI, Vega A, Mateo MB, Alonso Diaz de Durana MD, de la Hoz B, Del Pozo MD, Caballero T, Rosado A, Sanchez-Matas I, Teodosio C, Jara-Acevedo M, Mollejo M, Garcia-Montero A, Orfao A, Escribano L. Clinical, biological and molecular characteristics of systemic mast cell disorders presenting with severe mediator-related symptoms. J Allergy Clin Immunol 2010;125:1269-78.

21. Sonneck K, Florian S, Mullauer L, Wimazal F, Fodinger M, Sperr WR, Valent P. Diagnostic and subdiagnostic accumulation of mast cells in the bone marrow of patients with anaphylaxis: monoclonal mast cell activation syndrome. Int Arch Allergy Immunol 2006;142:158-64.

22. Alvarez-Twose I, Gonzalez de OD, SanchezMunoz L, Teodosio C, Jara-Acevedo M, Sanchez-Matas I, Matito A, Garcia-Montero A, Orfao A, Escribano L. Clinical, biological and molecular characteristics of mast cell activation disorders: a prospective study in 62 patients by the Spanish Network on Mastocytosis (REMA). J Allergy Clin Immunol 2009; 123:S141.

23. Johnson MR, Verstovsek S, Jorgensen JL, Manshouri T, Luthra R, Jones DM, BuesoRamos CE, Medeiros LJ, Huh YO. Utility of the World Heath Organization classification criteria for the diagnosis of systemic 
mastocytosis in bone marrow. Mod Pathol 2009:22:50-7.

24. Li L, Krilis SA. Mast-cell growth and differentiation. Allergy 1999;54:306-12.

25. Blume-Jensen P, Claesson-Welsh L, Siegbahn A, Zsebo KM, Westermark B, Heldin $\mathrm{CH}$. Activation of the human c-kit product by ligand-induced dimerization mediates circular actin reorganization and chemotaxis. EMBO J 1991;10:4121-8.

26. Galli SJ, Nakae S, Tsai M. Mast cells in the development of adaptive immune responses. Nat Immunol 2005;6:135-42.

27. Okayama Y, Kawakami T. Development, migration, and survival of mast cells. Immunol Res 2006;34:97-115.

28. Kitamura Y, Oboki K, Ito A. Molecular mechanisms of mast cell development. Immunol Allergy Clin North Am 2006;26: 387-405.

29. Kawakami T, Galli SJ. Regulation of mastcell and basophil function and survival by IgE. Nat Rev Immunol 2002;2:773-86.

30. Hamaguchi Y, Kanakura Y, Fijita J, Takeda SI, Nakano T, Tarui S, Honjo T, Kitamura Y. Interleukin 4 as an essential factor for in vitro clonal growth of murine connective tissue-type mast cells. J Exp Med 1987:165:268-73.

31. Matsuda H, Kannan Y, Ushio H, Kiso Y, Kanemoto T, Suzuki H, Kitamura Y. Nerve growth factor induces development of connective tissue- type mast cells in vitro from murine bone marrow cells. J Exp Med 1991;174:7-14.

32. Kitamura Y. Heterogeneity of mast cells and phenotypic change between subpopulations. Annu Rev Immunol 1989;7:59-76.

33. Metcalfe DD, Baram D, Mekori YA. Mast cells. Physiol Rev 1997;77:1033-79.

34. Yarden Y, Kuang WJ, Yang Feng T, Coussens L, Munemitsu S, Dull TJ, Chen E, Schlessinger J, Francke U, Ullrich A. Human proto-oncogene c-kit: a new cell surface receptor tyrosine kinase for an unidentified ligand. EMBO J 1987;6: 3341-51.

35. Spritz RA, Strunk KM, Lee ST, Lu-Kuo JM, Ward DC, Le PD, Altherr MR, Dorman TE, Moir DT. A YAC contig spanning a cluster of human type III receptor protein tyrosine kinase genes (PDGFRA-KIT-KDR) in chromosome segment $4 \mathrm{q} 12$. Genomics 1994;22:431-6.

36. Orfao A, Garcia-Montero AC, Sanchez L, Escribano L. Recent advances in the understanding of mastocytosis: the role of KIT mutations. Br J Haematol 2007;138:12-30.

37. Hartmann K, Wardelmann E, Ma YS, Merkelbach-Bruse S, Preussner LM, Woolery C, Baldus SE, Heinicke T, Thiele J, Buettner R, Longley BJ. Novel germline mutation of KIT associated with familial gastrointestinal stromal tumors and mastocytosis. Gastroenterology 2005;129:1042-6.
38. Zhang LY, Smith ML, Schultheis B, Fitzgibbon J, Lister TA, Melo JV, Cross NCP, Cavenagh JD. A novel K5091 mutation of KIT identified in familial mastocytosis - in vitro and in vivo responsiveness to imatinib therapy. Leuk Res 2006;30:373-8.

39. Tang X, Boxer M, Drummond A, Ogston P, Hodgins M, Burden AD. A germline mutation in KIT in familial diffuse cutaneous mastocytosis. J Med Genet 2004;41:89-93.

40. Nakagomi N, Hirota S. Juxtamembranetype c-kit gene mutation found in aggressive systemic mastocytosis induces imatinib-resistant constitutive KIT activation. Lab Invest 2007;87:365-71.

41. Furitsu T, Tsujimura $\mathrm{T}$, Tono $\mathrm{T}$, Ikeda $\mathrm{H}$, Kitayama H, Koshimizu U, Sugahara H, Butterfield JH, Ashman LK, Kanayama Y, Matsuzawa Y, Kitamura Y, Kanakura Y. Identification of mutations in the coding sequence of the proto-oncogene c-kit in a human mast cell leukemia cell line causing ligand-independent activation of c-kit product. J Clin Invest 1993;92:1736-44.

42. Tefferi A, Levine RL, Lim KH, Abdel-Wahab O, Lasho TL, Patel J, Finke CM, Mullally A, Li CY, Pardanani A, Gilliland DG. Frequent TET2 mutations in systemic mastocytosis: clinical, KITD816V and FIP1L1-PDGFRA correlates. Leukemia 2009;23:900-4.

43. Wilson TM, Maric I, Simakova O, Bai Y, Chan EC, Olivares N, Carter M, Maric D, Robyn J, Metcalfe DD. Clonal analysis of NRAS activating mutations in KIT-D816V systemic mastocytosis. Haematologica 2011;96:459-63.

44. Worobec AS, Akin C, Scott LM, Metcalfe DD. Mastocytosis complicating pregnancy. Obstet Gynecol 2000;95:391-5.

45. Escribano L, Akin C, Castells M, Orfao A, Metcalfe D. Mastocytosis: current concepts in diagnosis and treatment. Ann Hematol 2002a;81:677-90.

46. Escribano L, Akin C, Castells M, Schwartz LB. Current options in the treatment of mast cell mediator-related symptoms in mastocytosis. Inflamm Allergy Drug Targets 2006a;5:61-77

47. Sanchez-Matas I, Matito A, Gonzalez de Olano D, Alvarez-Twose I, Sanchez-Munoz L, de la Hoz Caballer B, Escribano L. Prevalence of hypersensitivity reactions to nonsteroidal anti-inflamatory drugs in 212 patients with mastocytosis in Spain. Allergy 2009; 64:574-5.

48. Matito A, Alvarez-Twose I, Morgado JM, Sanchez-Munoz L, Orfao A, Escribano L. Clinical impact of pregnancy in mastocytosis: a study of the Spanish Network on Mastocytosis (REMA) in 45 cases. Int Arch Allergy Immunol 2011;156:104-11.

49. Galli SJ, Dvorak AM, Dvorak HF. Basophils and mast cells: morphologic insights into their biology, secretory patterns, and function. Prog Allergy 1984;34:1-141.

50. Fukuoka Y, Xia HZ, Sanchez-Munoz LB, Dellinger AL, Escribano L, Schwartz LB. Generation of anaphylatoxins by human \{beta\}-tryptase from C3, C4, and C5. J Immunol 2008;180:6307-16.

51. Katz HR, Raizman MB, Gartner CS, Scott HC, Benson AC, Austen KF. Secretory granule mediator release and generation of oxidative metabolites of arachidonic acid via FC-IgG receptor bridging in mouse mast cells. J Immunol 1991;148:868-71.

52. Lobell RB, Arm JP, Raizman MB, Austen $\mathrm{KF}$, Katz HR. Intracellular degradation of FC gamma RIII in mouse bone marrow culture-derived progenitor mast cells prevents its surface expression and associated function. J Biol Chem 1993;268:1207-12.

53. Lobell RB, Austen KF, Katz HR. FcgammaR-mediated endocytosis and expression of cell surface FcgammaRIIbl and FcgammaRIIb2 by mouse bone marrow culturederived progenitor mast cells. J Immunol 1994;152:811-8.

54. Marshall JS. Mast-cell responses to pathogens. Nat Rev Immunol 2004;4:787-99.

55. Castells M. Mast cell mediators in allergic inflammation and mastocytosis. Immunol Allergy Clin North Am 2006;26:465-85.

56. Schwartz LB. Tryptase: a mast cell serine protease. Methods Enzymol 1994;244:88100.

57. Castells M, Irani AM, Schwartz LB. Evaluation of human peripheral blood leukocytes for mast cell tryptase. J Immunol 1987; 138:2184-9.

58. Schwartz LB, Min HK, Ren SL, Xia HZ, Hu J, Zhao W, Moxey G, Fukuoka Y. Tryptase precursors are preferentially and spontaneously released, whereas mature tryptase is retained by HMC- 1 cells, mono-mac- 6 cells, and human skin-derived mast cells. J Immunol 2003;170:5667-73.

59. Weber A, Knop J, Maurer M. Pattern analysis of human cutaneous mast cell populations by total body surface mapping. Br J Dermatol 2003;148:224-8.

60. Hollmann TJ, Brenn T, Hornick JL. CD25 expression on cutaneous mast cells from adult patients presenting with urticaria pigmentosa is predictive of systemic mastocytosis. Am J Surg Pathol 2008;32:139-45.

61. Sotlar K, Horny HP, Simonitsch I, Krokowski M, Aichberger KJ, Mayerhofer M, Printz D, Fritsch G, Valent P. CD25 indicates the neoplastic phenotype of mast cells - a novel immunohistochemical marker for the diagnosis of systemic mastocytosis (SM) in routinely processed bone marrow biopsy specimens. Am J Surg Pathol 2004;28:1319-25.

62. Baumgartner C, Sonneck K, Krauth MT, Kneidinger M, Fodinger M, Hauswirth AW, Mullauer L, Valent P. Immunohistochemi- 
cal assessment of CD25 is equally sensitive and diagnostic in mastocytosis compared to flow cytometry. Eur J Clin Invest 2008;38:326-35.

63. Sotlar K, Cerny-Reiterer S, Petat-Dutter K, Hessel H, Berezowska S, Mullauer L, Valent P, Horny HP. Aberrant expression of CD30 in neoplastic mast cells in high-grade mastocytosis. Mod Pathol 2011;24:585-95.

64. Maric I, Calvo KR. Mastocytosis: the new differential diagnosis of CD30-positive neoplasms. Leuk Lymphoma 2011;52:732-3.

65. Horny HP, Valent P. Diagnosis of mastocytosis: general histopathological aspects, morphological criteria, and immunohistochemical findings. Leuk Res 2001;25:543-51.

66. Horny HP, Lange K, Sotlar K, Valent P. Increase of bone marrow lymphocytes in systemic mastocytosis: reactive lymphocytosis or malignant lymphoma? Immunohistochemical and molecular findings on routinely processed bone marrow biopsy specimens. J Clin Pathol 2003;56:575-8.

67. Orfao A, Escribano L, Villarrubia J, Velasco JL, Cerveró C, Ciudad J, Navarro JL, San Miguel JF. Flow cytometric analysis of mast cells from normal and pathological human bone marrow samples. Identification and enumeration. Am J Pathol 1996; 149:1493-9.

68. Escribano L, Navalón R, Núñez R, Díaz Agustín B, Bravo P. Flow cytometry immunophenotypic analysis of human mast cells. In: Current Protocols in Cytometry. Robinson JP, Darzynkiewicz Z, Dean P, Orfao A, Rabinovitch P, Wheeless L (eds). New York: John Wiley \& Sons, Inc; 2000: 6.6.1-6.18.

69. Escribano L, Diaz-Agustin B, Nunez R, Prados A, Rodriguez R, Orfao A. Abnormal expression of CD antigens in mastocytosis. Int Arch Allergy Immunol 2002b; 127:127-32.

70. Escribano L, Garcia Montero AC, Nunez R, Orfao A. Flow cytometric analysis of normal and neoplastic mast cells: role in diagnosis and follow-up of mast cell disease. Immunol Allergy Clin North Am 2006b;26: 535-47.

71. Sanchez-Munoz L, Teodosio C, Morgado JM, Escribano L. Immunophenotypic characterization of bone marrow mast cells in mastocytosis and other mast cell disorders. Methods Cell Biol 2011b;103:333-59.

72. Escribano L, Orfao A, Villarrubia J, Cerveró C, Velasco JL, Martin F, San Miguel JF, Navarro JL. Expression of lymphoid-associated antigens in mast cells: report of a case of systemic mast cell disease. Br J Haematol 1995;91:941-3.

73. Escribano L, Orfao A, Villarrubia J, Martín F, Madruga JI, Cuevas M, Velasco JL, Rios A, San Miguel JF. Sequential immunophenotypic analysis of mast cells in a case of systemic mast cell disease evolving to a mast cell leukemia. Cytometry 1997;30:98-102.

74. Escribano L, Orfao A, Villarrubia J, Díaz Agustín B, Cerveró C, Ríos A, Velasco JL,
Ciudad J, Navarro JL, San Miguel JF. Immunophenotypic characterization of human bone marrow mast cells. A flow cytometric study of normal and pathological bone marrow samples. Anal Cell Pathol 1998c;16:151-9.

75. Escribano L, Díaz Agustín B, Bravo P, Navalón R, Almeida J, Orfao A. Immunophenotype of bone marrow mast cells in indolent systemic mast cell disease in adults. Leuk Lymphoma 1999;35:227-35.

76. Escribano L, Díaz Agustín B, Bellas C, Navalón R, Núñez R, Sperr W, Schernthaner $G$, Valent $P$, Orfao A. Utility of flow cytometric analysis of mast cells in the diagnosis and classification of adult mastocytosis. Leuk Res 2001;25:563-70.

77. Bodni RA, Sapia S, Galeano A, Kaminsky A. Indolent systemic mast cell disease: immunophenotypic characterization of bone marrow mast cells by flow cytometry. J Eur Acad Dermatol Venereol 2003;17: 160-6.

78. Pardanani A, Kimlinger T, Reeder T, Li CY, Tefferi A. Bone marrow mast cell immunophenotyping in adults with mast cell disease: a prospective study of 33 patients. Leuk Res 2004;28:777-83.

79. Escribano L, Orfao A, Diaz-Agustin B, Villarrubia J, Cervero C, Lopez A, Marcos MA, Bellas C, Fernandez-Canadas S, Cuevas M, Sanchez A, Velasco JL, Navarro JL, Miguel JF. Indolent systemic mast cell disease in adults: immunophenotypic characterization of bone marrow mast cells and its diagnostic implications. Blood 1998b;91:2731-6.

80. Teodosio C, Garcia-Montero AC, Jara-Acevedo M, Alvarez-Twose I, Sanchez-Munoz L, Almeida J, Morgado JM, Matito A, Escribano L, Orfao A. An immature immunophenotype of bone marrow mast cells predicts for multilineage D816V KIT mutation in systemic mastocytosis. Leukemia 2011, Epub ahead of print.

81. Morgado JM, Sanchez-Munoz L, Teodosio CG, Jara-Acevedo M, Alvarez-Twose I, Matito A, Fernandez-Nunez E, Garcia-Montero A, Orfao A, Escribano L. Immunophenotyping in systemic mastocytosis diagnosis: 'CD25 positive' alone is more informative than the 'CD25 and/or CD2' WHO criterion. Mod Pathol 2012, Epub ahead of print.

82. Escribano L, Orfao A, Díaz Agustín B, Cerveró C, Herrero S, Villarrubia J, Bravo $\mathrm{P}$, Torrelo A, Montero T, Valdemoro M, Velasco JL, Navarro JL, San Miguel JF. Human bone marrow mast cells from indolent systemic mast cell disease constitutively express increased amounts of the CD63 protein on their surface. Cytometry 1998a;34:223-8.

83. Cerveró C, Escribano L, Orfao A, Díaz Agustín B, Bravo P, Villarrubia J, GarcíaSanz R, Velasco JL, Herrera P, Vargas M,
González M, Navarro JL, San Miguel JF. Expression of bcl-2 by human bone marrow mast cells and its overexpression in mast cell leukemia. Am J Hematol 1999;60:191-5.

84. Diaz-Agustin B, Escribano L, Bravo P, Herrero S, Nunez R, Navalon R, Navarro L Torrelo A, Cantalapiedra A, Del Castillo L, Villarrubia J, Navarro JL, San Miguel JF, Orfao A. The CD69 early activation molecule is overexpressed in human bone marrow mast cells from adults with indolent systemic mast cell disease. Br J Haematol 1999;106:400-5.

85. Hauswirth AW, Escribano L, Prados A, Nunez R, Mirkina I, Kneidinger M, Florian S, Sonneck K, Vales A, Schernthaner GH, Sanchez-Munoz L, Sperr WR, Buhring HJ, Orfao A, Valent P. CD203c is overexpressed on neoplastic mast cells in systemic mastocytosis and is upregulated upon IgE receptor cross-linking. Int $\mathrm{J}$ Immunopathol Pharmacol 2008;21:797-806.

86. Nagata H, Worobec AS, Oh CK, Chowdhury BA, Tannenbaum S, Suzuki Y, Metcalfe DD. Identification of a point mutation in the catalytic domain of the protooncogene c-kit in peripheral blood mononuclear cells of patients who have mastocytosis with an associated hematologic disorder. Proc Nat Acad Sci USA 1995;92:10560-4.

87. Sotlar K, Escribano L, Landt O, Möhrle S, Herrero S, Torrelo A, Lass U, Horny HP, Bültmann B. One-step detection of c-kit point mutations using PNA-mediated PCRclamping and hybridization probes. Am J Pathol 2003;162:737-46.

88. Kocabas CN, Yavuz AS, Lipsky PE, Metcalfe DD, Akin C. Analysis of the lineage relationship between mast cells and basophils using the $c$-kit D816V mutation as a biologic signature. J Allergy Clin Immunol 2005;115:1155-61.

89. Tan A, Westerman D, McArthur GA, Lynch K, Waring P, Dobrovic A. Sensitive detection of KIT D816V in patients with mastocytosis. Clin Chem 2006;52:2250-7.

90. Schumacher JA, Elenitoba-Johnson KS Lim MS. Detection of the c-kit D816V mutation in systemic mastocytosis by allelespecific PCR. J Clin Pathol 2008;61:109-14.

91. Lim KH, Tefferi A, Lasho TL, Finke C, Patnaik M, Butterfield JH, McClure RF, Li CY, Pardanani A. Systemic mastocytosis in 342 consecutive adults: survival studies and prognostic factors. Blood 2009; 1 13:572736.

92. Molderings GJ, Meis K, Kolck UW, Homann J, Frieling T. Comparative analysis of mutation of tyrosine kinase kit in mast cells from patients with systemic mast cell activation syndrome and healthy subjects. Immunogenetics 2010;62:721-7.

93. Kristensen T, Vestergaard H, Moller MB. Improved detection of the KIT D816V mutation in patients with systemic 
mastocytosis using a quantitative and highly sensitive real-time qPCR assay. J Mol Diagn 2011;13:180-8.

94. Sotlar K, Marafioti T, Griesser H, Theil J, Aepinus C, Jaussi R, Stein H, Valent P, Horny HP. Detection of c-kit mutation Asp 816 to $\mathrm{Val}$ in microdissected bone marrow infiltrates in a case of systemic mastocytosis associated with chronic myelomonocytic leukaemia. J Clin Pathol Mol Pathol 2000;53:188-93.

95. Taylor ML, Sehgal D, Raffeld M, Obiakor H, Akin C, Mage RG, Metcalfe DD. Demonstration that mast cells, T cells, and B cells bearing the activating kit mutation $\mathrm{D} 816 \mathrm{~V}$ occur in clusters within the marrow of patients with mastocytosis. J Mol Diagn 2004;6:335-42.

96. Yavuz AS, Lipsky PE, Yavuz S, Metcalfe DD, Akin C. Evidence for the involvement of a hematopoietic progenitor cell in systemic mastocytosis from single-cell analysis of mutations in the c-kit gene. Blood 2002;100:661-5.

97. Kopp P, Jaggi R, Tobler A, Borisch B, Oestreicher M, Sabacan L, Jameson JL, Fey MF. Clonal X-inactivation analysis of human tumours using the human androgen receptor gene (HUMARA) polymorphism: a non-radioactive and semiquantitative strategy applicable to fresh and archival tissue. Mol Cell Probes 1997;11:217-28.

98. Wu Y, Basir Z, Kajdacsy-Balla A, Strawn E, Macias V, Montgomery K, Guo SW. Resolution of clonal origins for endometriotic lesions using laser capture microdissection and the human androgen receptor (HUMARA) assay. Fertil Steril 2003;79:710-7.

99. Schwartz LB. Clinical utility of tryptase levels in systemic mastocytosis and associated hematologic disorders. Leuk Res 2001;25:553-62.

100. Schwartz LB. Diagnostic value of tryptase in anaphylaxis and mastocytosis. Immunol Allergy Clin North Am 2006;26:451-63.

101. Sperr WR, El-Samahi A, Kundi M, Girschikofsky M, Winkler S, Lutz D, Endler G, Rumpold H, Agis H, Sillaber C, Jager U, Valent P. Elevated tryptase levels selectively cluster in myeloid neoplasms: a novel diagnostic approach and screen marker in clinical haematology. Eur J Clin Invest 2009;39:914-23.
102. Schwartz LB, Irani AMA. Serum tryptase and the laboratory diagnosis of systemic mastocytosis. Hematol Oncol Clin North Am 2000; 14:641-57.

103. Kushnir-Sukhov NM, Brittain E, Reynolds JC, Akin C, Metcalfe DD. Elevated tryptase levels are associated with greater bone density in a cohort of patients with mastocytosis. Int Arch Allergy Immunol 2006; 139:265-70.

104. Ferrer M, Nunez-Cordoba JM, Luquin E, Grattan CE, De la Borbolla JM, Sanz ML, Schwartz LB. Serum total tryptase levels are increased in patients with active chronic urticaria. Clin Exp Allergy 2010;40:1760-6.

105. Sperr WR, Hauswirth AW, Valent P. Tryptase a novel biochemical marker of acute myeloid leukemia. Leuk Lymphoma 2002a;43:2257-61.

106. Sirvent AE, Gonzalez C, Enriquez R, Fernandez J, Millan I, Barber X, Amoros F. Serum tryptase levels and markers of renal dysfunction in a population with chronic kidney disease. J Nephrol 2010;23:282-90.

107. Metcalfe DD, Schwartz LB. Assessing anaphylactic risk? Consider mast cell clonality. J Allergy Clin Immunol 2009;123:687-8. 
Copyright of International Journal of Laboratory Hematology is the property of Wiley-Blackwell and its content may not be copied or emailed to multiple sites or posted to a listserv without the copyright holder's express written permission. However, users may print, download, or email articles for individual use. 